\title{
Interest-Free Bonds and Central Banking Monetary Instruments
}

\author{
Bijan Bidabad \\ Senior Economist and Islamic Banking Adviser \\ Bank Melli Iran, Tehran, Iran \\ E-mail: bijan@bidabad.com
}

Abul Hassan

Economist and Senior Research Fellow

Markfield Institute of Higher Education, United Kingdom

E-mail: abul.hassan@islamic-foundation.org.uk

Mohamed Sami Ben Ali

Assistant Professor of Economics

IHEC Business School of Sousse, University of Sousse, Tunisia

E-mail: MohamedSami.benali@ihecso.rnu.tn

Mahmoud Allahyarifard

Islamic Banking Expert, Research and Development Department

Bank Melli Iran, Tehran, Iran

E-mail: m_allahyarifard@bmi.ir

Received: October 23, $2010 \quad$ Accepted: November 15, $2010 \quad$ doi:10.5539/ijef.v3n3p234

\begin{abstract}
Since conventional bonds include Riba (interest), they are not allowed to be used in the Central Banking under the Islamic economics system. By introducing various interest-free bonds for central bank, commercial banks, treasury and corporate entities in domestic and foreign currencies as substitutes for traditional bonds, this paper provides an Islamic financial innovations strategies which will be accomplishing the infrastructures for development of financial markets in both domestic as well as foreign financial markets. These asset-based papers have no pre-fixed interest coupons, and are based upon "loan equal to future debt" or, "debt equal to future loan" with "time-drawing right" which is handed to the other party and outlines the primary market. The secondary market has been designed based on information technology. Furthermore, these interest-free financial innovations include no-short pricing of the securities below its face value, and will substitute for traditional bonds and will stabilizing domestic and foreign exchange markets.
\end{abstract}

Keywords: Bond, Islamic economy, Interest-free Central Banking

\section{Introduction}

In Islamic economics, the main functions of a central bank are to maintain price stability and prosperity of the whole humanity (Chapra, 1985). Although this system is indifferent from the conventional concept of central banking, the role of an Islamic central bank is to conduct its monetary operation by using Islamic monetary instruments that need to be free from interest, links with the business sector activities and giving value added into the economy (Mills and Presley, 1999).

The main constraint of any instrument is that its operations must have a counterpart with the real project(s)/asset(s) in the real sector. From a conventional viewpoint, monetary contraction/expansion operations may not directly link with the real projects or business activities (Rabin, 2004). For instance, monetary contraction is done by selling central bank monetary instruments (securities) which do not need to have a counterpart or asset backed in the real 
sector. This contradiction is one of the main constraints of applying Islamic instruments in an interest-free central banking system.

Islamic finance is gaining acceptance all over the world and is nowadays regarded as a serious competitor to "conventional finance". During the last three decades, Islamic banking matured into a viable alternative model of financial intermediation and gained credibility as witnessed by the establishment of a large number of Islamic financial institutions all over the world. A recent survey by Fadzlan (2007), states that more than 160 Islamic financial institutions exist around the world. Furthermore, several multinational banks started establishing Islamic branches and offering Islamic financial products all over the world.

The Islamic financing activity is based on the Islamic faith and must stay within the limits of Islamic Law or the Shariaa's compliant in all of its actions and deeds. The system is different from the traditional one mainly by the fact that rather than fulfilling the only function of financial intermediation as does the conventional banking system, it fulfils the role of direct partnership (Ben Khediri, Ben Ali and Ben-Khedhiri, 2010). The development of the Islamic banking industry demands appropriate Islamic monetary instruments to manage the industry and economy in general. Besides, there is great need both from countries such as Sudan and Iran that eliminated the conventional banking system and substituted it with a complete Islamic one, or from others countries, such as Bangladesh, Brunei, Indonesia, Jordan, Kuwait, Malaysia and the United Arab Emirates, that are making monopolistic status (Haron, 1996). In this regard, Brunei, Indonesia, Malaysia, Sudan and UAE have already launched some Islamic monetary instruments as a first step in this direction Sukuk is the main instruments). However, those instruments are in majority debatable contracts among Islamic scholars and the majority of them declared that such contracts are not Shariaa compliant (Mansoori, 2010).

Prohibition of Riba (interest) in Islam prevents using traditional banking or financial instruments which has skepticism of involving Riba. Since interest (riba) is involved in the most of the traditional banking instruments, and in order to implement monetary policies; there is needed to innovate new financial instruments which should comply with rules of Shariaa.

Interest-free securities (Islamic securities) have become increasingly popular over the last decade, both as a means of rising government finance through sovereign issues, and as a way of corporate entities obtaining funding through the offer of corporate sukuk (Islamic bond). In 2000 there were only three sukuk-type interest-free bonds worth $\$ 336$ million issues. In 2004 there were 64 issues worth almost $\$ 7$ billion, and in 2007 the figure has exceeded $\$ 90$ billion with more 119 issues fully subscribed (Moody's, 2007; 2008). The advantage of sukuk is that they are compliant with Shariaa (Wilson, 2008).

In spite of financial and economic needs for debt-based papers, there is dirt of study which concentrated to use interest-free bond as a central bank's monetary instrument. This paper examines the potential for some of the interest-free bonds as new instruments for central banking operation based on Shariaa, which could be attractive for generating funds by the central banks under both conventional as well as an Islamic banking systems. To our knowledge, this is the first paper to address a theoretical background for such issue.

The rest of the paper is organized as follows: Section 2 discusses on the traditional monetary instruments. Section 3 presents our proposition of bonds in domestic money and in foreign exchange. Section 4 assesses the general monetary effects of issuance of theses Islamic bonds. We also focus in this section on their particular effects on inflation, interest and exchange rates. Section 5 discusses the transaction of theses bonds in secondary markets based on information technology. Finally section 6 draws conclusion.

\section{Traditional Monetary Policy Instruments}

In general, monetary policy is a collection of instruments which are used to fulfill macro-economic goals or reduction of damages of the performance of monetary system and controlling liquidity in the economy. The monetary authorities use different instruments which can be generally classified into two groups: quantitative and qualitative monetary instruments. Usually, quantitative monetary instruments change money supply through monetary expansion mechanism. This mechanism is practically the way that money in the economy is created. Qualitative instruments are those monetary arrangements which guide the distribution and allocation of credit within different economic sectors. Interest rate is a central concept in this regard.

In economic literature, interest rate is defined as a variable which is created by supply and demand intersection of money resources. It is not regarded as a monetary instrument. But it has a vast capability for re-allocation of resources which can act an important role in the economy. In other words, banks can decrease the demand for money by increasing interest rate and increase the supply of deposit sources. Since monetary expansion mechanism operates through money circulation between people and commercial banks, hence all quantitative monetary 
instruments affect both liquidity and the economy.

On the other hand, open market operation is one of the most important quantitative instruments. In this method, monetary authorities buy or sell bonds and valuable papers and change the amount of high powered money in the economy. In a traditional monetary system, transaction of these papers is based upon variable interest rates which involve usury (Riba) and therefore, cannot be used in the interest-free or Islamic banking system.

As a part of the monetary policy, in order to control liquidity, monetary authorities some times force the banks to keep a certain percentage of their assets in the form of bonds. The purpose of this reserve requirement policy is to prevent money expansion through reduction of free reserves of banks.

Discount window is also a third type of quantitative monetary instruments. In this instrument, the commercial banks can sell some of their financial papers at discounted interest rates to central bank to solve their liquidity needs. By changing this rate, central bank can affect the banks' resources and credit capability. This instrument is very helpful when banks need loan to get enough liquidity. But since this method uses interest rate, hence this instrument can not be used in the banking system operating under Islamic business ethics.

Legal reserve rate is known as credit brake, is another quantitative monetary instrument. It has many capabilities in harnessing banking credits. This rate has a vast range of effects on liquidity in the economy, therefore, it is considered as an important monetary instrument in controlling credit facilities through controlling monetary expansion mechanism. With this rate, an obligation is applied on banks which is not an interest-bearing. However, slightly increasing this rate may become costly for banks, since, it blocks some of their resources in central bank.

Another group of monetary instruments are called qualitative which practically tries to divert the financial resources through limiting or encouraging credits to those sectors that authorities prefer. Limiting banks in providing credit, defining credit ceilings for banks, and defining the method of allocation of deposit funds are also considered as qualitative instruments. Generally, it is considered that the qualitative instruments do not have the necessary capabilities of helping monetary authorities to reach economic goals efficiently.

In view of the above discussions, it should be mentioned here that the monetary instruments of the conventional banking system cannot help a central bank for controlling liquidity in an Islamic economy. Therefore, there is a need to innovate appropriate monetary instruments suitable under Riba (interest) free conditions. Hence, implementation of monetary policy with Shariaa compliant monetary instruments is an important challenge before a central bank which will operate under Islamic economic system.

\section{New monetary instruments for a Riba-free banking}

Creation of debt by deferred trading is allowed in Islamic economics but sale of debt through conventional style is not permitted in Islamic banking system. There are three main debt papers: Coupon Bond, Zero Coupon Bond, and Mortgage Backed Securities (MBS). Predominant Riba-based form of Coupon Bonds and their transactions at a lower price than face value, regardless of not receiving any interest until maturity, has some latent interests and are not applicable in Islamic central banking. Furthermore, on one hand, although Zero Coupon Bonds contain transactions pillars, hence using debt and substance purchases, their transactions are not allowed based on Sahriaa rulings. On the other hand, the Mortgage Backed Securities are derivative securities and involve interest. So theses papers are inapplicable in Islamic system. In order to use appropriate monetary policies in an interest-free central banking system that is based mostly upon transaction of bonds, there is a substantial need for financial innovations which will not only Shariaa compliant but also be efficient.

In this section, the four Shariaa compliant interest-free bonds are introduced. These interest-free bonds may also be used as secure financial asset-backed instruments for central bank, commercial banks, treasury and corporate entities under conventional system as well as Islamic system. Furthermore, these bonds may be issued in domestic money and foreign currencies as well.

\subsection{Interest-free (Riba-free) Bonds}

Actually, an interest-free bond means a certificate which is a financial paper that observes the right for the lender to borrow the equal amount to his lending from the borrower. The lender can sell his certificate in the market at market price. In this bond type no interest rate is defined, but the market value of bond is determined by the market at each transaction and the return of bond is not fixed and not predetermined. The interest-free bonds will differ according to their due date (short, medium and long term).

Interest-free bond can be developed as an alternative to debt (bond) by central bank, commercial bank and specialized bank or monetary and credit institutions under the supervision of the central bank or other corporate entities in accordance with the principles of Shariaa. In this paper, we introduce four interest-free bonds: (i) 
interest-free bonds to be issued by central bank, (ii) interest-free bonds to be issued by commercial and specialized banks, and money and credit institutions under the supervision of the central bank; (iii) treasury interest-free bonds to be issued by government treasury; and (iv) commercial interest-free bonds to be issued by private or corporate entities with special guarantees.

These interest-free Shariaa compliant bonds to be issued by central banks or other institutions will have substantial differences with conventional commercial bonds, papers linked to capital, and asset-backed papers as well as zero coupon bonds. The main difference between the interest-free and conventional bonds: former will have no pre-fixed interest rate, and the funds will be offered to other party in form of "debt equal to future loan", or "loan equal to future debt" with "time-drawing right". This also differentiates interest-free bonds from conventional bonds as the latter proceed over the interest bearing securities, whereas interest-free bonds are basically investment certificates consist of ownership claims. In other words, the interest-free bonds will represent ownership of an asset. Like the conventional debt securities, interest-free bonds may be issued for a fixed time period rather than perpetuity as with the equity. The time period can vary similar to conventional treasury bills.

These papers can be transacted in secondary market among banks and others institutions. In this regard interest-free bonds pricing will be formed on a base of demand for and supply of money rather than fixed interest rates for fixed time period. Thus, the interest rate of these bonds is zero but their returns via volatility of bonds' prices in the market are not fixed. Thus the interest rate rigidity is vanished and when the economy goes toward the recession returns of interest-free bonds will become lower and reduces the cost of using money resources; and vice versa for the case of going the economy toward prosperity. That is interest-free bond has a built-in automatic adjustment mechanism which stabilizes the economy. In other world, we can say that their prices will be proportional to capital return of the economy and it does not involve in Riba (Bidabad, 2004).

Interest-free bonds will be issued under certain conditions and face value by central bank, commercial, specialized and development banks; and by the private corporate entities. It may be pointed out that commercial, specialized and development banks; money and credit institutes and financial institutions who have prudential and legal reserves at central bank, or private corporate entities (by considering special guarantees) by buying these papers will have the right to use interest-free loan equal to their holding bonds and will pay it back to the issuer at maturity.

Accordingly, by buying \$A bonds with maturity of $\mathrm{N}$ months, the buyer will have the right to obtain $\$ \mathrm{~A}$ interest-free loan for a period of $\mathrm{N}$ months from the issuer of the bonds. The buyer and seller will agree on fixing combinations of $\$ \mathrm{~A}$ and $\mathrm{N}$ months so that the buyer can choose smaller, equal or larger than one ratios from $\$ \mathrm{~A}$ in proportion with $\mathrm{N}$ months. In this case, the result of the amount of money will be multiplied by time which will be equal to $\mathrm{A} \times \mathrm{N}$. In other words, for example, buyer instead of A Dollars, can borrow A/2 Dollars for $2 \mathrm{~N}$ months at the $\mathrm{N}^{\text {th }}$ month, or $\$ \mathrm{~A} / 3$ for $3 \mathrm{~N}$ months at the $\mathrm{N}^{\text {th }}$ month. Where, in both cases the result will be equal to $\mathrm{A} \times \mathrm{N}$. That is: $(\mathrm{A} / 2) \times(2 \mathrm{~N})=(\mathrm{A} / 3) \times(3 \mathrm{~N})=\mathrm{A} \times \mathrm{N}$ or generally speaking, instead of $\$ \mathrm{~A}$, we will receive $\$ \mathrm{~A} / \mathrm{k}$ for $\mathrm{k} \times \mathrm{N}$ months after the $\mathrm{N}$ months. The parameter $\mathrm{k}$ can be any agreed figure accepted mutually by the parties, or offered by the buyer. This procedure is depicted by figure 1 .

Generally, these bonds practically may have two time periods and two maturity dates (as shown in the figure 1). The first period is equal to $\mathrm{N}$ months from the selling time to first maturity, and the second time period is from the first maturity date $(\mathrm{N})$ until the payback date of funds $(\mathrm{kN}+\mathrm{N})$ or second maturity date. The first maturity is when the seller of papers is obliged to provide the loan equal to A dollars for $\mathrm{N}$ months, or $\mathrm{A} / \mathrm{k}$ dollars for $\mathrm{kN}$ months to the buyer. Therefore, the first maturity occurs at the end of $\mathrm{N}$ months. The second maturity is the end of contract when the seller will receive back his funds after $\mathrm{kN}+\mathrm{N}$ months after selling time.

Since banks have prudential and legal reserves at central bank, they will not face loan defaults. In this regard, they can transact these papers in the "interest-free secondary market". The buyers and sellers of this market generally may be commercial, specialized and development banks and money and credit institutes and reputable funds under the supervision of central bank which have prudential and legal reserves at central bank. In addition, government and private sector can enter this market by considering certain conditions.

\subsection{Interest-free (Riba-free) Foreign Exchange Bonds}

It is possible to design and issue interest-free (Islamic) foreign exchange bonds similar to interest-free bonds. In this regard, all four kinds of bonds mentioned earlier, can be issued. The sellers and buyers of these papers will also be similar with above mentioned interest-free bonds transactions and will have no significant difference except for the amount of transaction which may be numerated in one or two exchange rates for the two mentioned time periods. Neither cases, especially when in the first period one foreign exchange is used and in the other period, another foreign exchange is used, create no suspicion of Riba involvement. Therefore, according to the above classification, four kinds of interest-free foreign exchange bonds may be designed which include: (i) central bank interest-free 
foreign exchange bonds to be issued by central bank; (ii) interest-free foreign exchange bonds to be issued by commercial, specialized and development banks, and credit and money financial institutes which are under the supervision of central bank; (iii) interest-free foreign exchange (treasury) bonds to be issued by government treasury; (iv) interest-free foreign exchange (corporate) bonds to be issued by corporate entities as previously mentioned should involve special guarantees. In this regard, foreign banks can also enter into this market by agreement of central bank to issue interest-free foreign exchange bonds.

The monetary effects of interest-free foreign exchange bonds will be similar to interest-free bonds, plus the capability of stabilizing foreign exchange supply and demand in the economy. Furthermore, the central bank can adjust and manage exchange rate by this instrument and affect exchange rate by changing foreign exchange supply. When the bonds' face values for both periods would be in the same foreign exchange, there will be arrangements for risk coverage (hedging) in the second period. In the case of different foreign exchange to be used for the second period, the same arrangements will be applied for the second period to cover foreign exchange risk. In addition to central bank, other bonds' buyers can also use it to cover their future foreign exchange risk.

\section{Effects of issuance of Islamic bonds}

Interest-free bond will serve as an important instrument for resource mobilization and will be a primary vehicle for the development of Islamic capital market. Sole (2007) argues that expanding range of financing opportunities by different institutions by developing sukuk - as an interest-free bond - is likely to deepen the financial sector as well as economy as a whole. Therefore, the effects of issuing these bonds by central bank, commercial banks, government treasury and private entities separately will enormously contribute in real sector economy. The following subsection discusses their general economic, financial and monetary effects as well as their particular probable effects on inflation, interest and exchange rates.

\subsection{Economic, Financial and Monetary Effects of Interest-free Bonds}

When Interest-free bonds are issued by central bank, practically it will decrease the free balances of banks and blocks them by central bank. It will also oblige the central bank to provide banks with the same amount in the second time period. After the end of the second period, central bank will line out the issued papers. Since these operations will affect high powered money, it may create the contractionary effects in the first period and expansionary effects in the second period.

When the interest-free bonds are issued and sold by commercial, specialized or development banks, - in addition to increase the amount of these papers in the market - will not increase the liquidity. This is because these operations will likely to be lagged borrowing of banks from each others. Hence, as much as free balances of one bank will decrease, the free balances of others will increase in the first time period, and vice versa will be in the second period. This will result no changes in liquidity of the economy. It will only finance the needs of banks which may not have enough liquidity and will adjust liquidity risk of the banks. In this case, seller and buyer seem to be from the same category of banks. If government or people buy these bonds, there will be no change in the liquidity. However, if central bank buys these papers, it will have expansionary effects in the first period and contractionary effects in the second period on the economy.

As cited before, interest-free bonds can be issued and supplied by government treasury. In this case, necessary conditions will be available for government to finance government budget and government can adjust her fiscal policies by buying and selling these bonds. If banks or private people/entities buy the government-issued interest-free bonds, then it will have no practically effect on the level of liquidity. In other case, if central bank buys these papers, it will have expansionary effects in the first time period and contractionary effects in the second period.

Private corporate entities and institutes can also issue interest-free bonds. In this case, appropriate mechanism should be arranged to decrease the probability of default to zero. For this reason, the seller will provide a (first) bank guarantee equal to the face value of bonds at the time of issuance and surrenders it to buyers. At the end of the first time period the buyer will be obliged to surrender the same bank guarantee to seller of bonds. After returning the funds back from the seller to buyer - at the end of the first period - the first guarantee is canceled. Another (second) bank guarantee is to be issued again for the second part of borrowing. At the end of the second time period -after returning the funds back from buyer to seller - the second guarantee will also be cancelled. The monetary effect in this case again is neutral, but it makes the allocation of money resources better.

\subsection{Effects on Inflation, Interest and Exchange Rates}

As previously shown, buying and selling interest-free bonds by central bank have contractionary effects in the first time period and expansionary effects in the second period. Therefore, central bank will define A, N, or k according 
to the position of the economy in recovery, prosperity, recession and crisis during business cycles to decrease the severity of economic fluctuation. This policy is similar to fine tuning monetary policy in conventional central banking.

Since these bonds can be transacted in the secondary interest-free bond market, they can have automatic adjustment mechanism through relationship of the price of the papers and interest rate. Whenever interest rate is high, the transaction price of the interest-free bonds will fall in the first time period, and will increase the incentive for banks to put their sources at central bank. Hence, they can obtain more funds in the second time period. During prosperity, when interest rate is high, it will limit the free balances of banks and will prevent the expansion of business cycle domain. On the contrary, when interest rates are low, the price of interest-free bonds will increase during the first time period and decrease the incentive for banks to buy these papers from central bank to obtain more funds in the second time period. This means that during economic crisis, when interest rates are low, it will expand the free bank balances and will not let business cycle to be expanded and aggravate the crisis. Central bank can adjust the supply of these bonds through their prices and by changing supply of high powered money affects liquidity and hence will affect the interest rates. Accordingly, interest-free bonds can substitute conventional bonds in Islamic central banking, because they have zero interest rate.

When expected inflation and expected interest rates are different in first and second time periods, analysis of the performance of these papers will be somehow different. If the expected natural interest rate in the second time period is more or less than the first time period, it will have different effects on supply and demand of interest-free banking bonds. The more is the expected natural interest rate in the second period, the more will be the price of bonds in the first period and vice versa. Similarly, the less is the expected natural interest rate in the second period, the less will be the bond price in the first financial period. This issue is very important from central banks' point of view in adjusting proper monetary policy for stabilizing economic activities. In addition, it causes expectations to have essential role in credit behavior of banks. This means that if banks expect increase (or decrease) in natural interest rate during the second period, they will adapt increasing (or decreasing) policy for supplying bonds. From economic point of view, this mechanism can be a factor in dampening oscillation of business cycles.

The mechanism of issuing bonds is different in continuous stable inflation case. If expected inflation rate is not different in both periods, inflation will not affect the bonds' prices. Because, both the buyer and seller expect that the rate of returns of interest-free bonds are the same in two successive periods with fixed expected inflation rate (Ceteris Paribus); and the price of interest-free bonds does not change due to inflation expectation. If it is different, it will be expected different prices for bonds in secondary market. If the average expected inflation rate in the first period is less than average expected inflation rate in the second period, then the bond prices will be higher in the first period than the second period. On the other hand, if the average expected inflation rate in the first period is higher than average expected interest rate in the second period, we will have an opposite case and bond prices in the first period will be less than the second period.

The interest rates of deposits and credit facilities in other markets have also important effects on supply and demand and price of interest-free bonds in the secondary market can be studied in two financial periods and according to the length of these periods and at different parts of business cycle.

The effects of issuance of interest-free bonds on exchange rate flows to foreign exchange sector through the created monetary and exchange effects. Change of supply of domestic currency encountering foreign exchange supply, will affect the economy through monetary channels and will make differences in internal and external interest rates.

\section{Transaction of Interest-free bonds in secondary markets}

Interest-free bond transactions will be based on information technology infrastructures. With a defined face value, these interest-free bonds will be issued on internet platform of Non-usury Scripless Security Settlement System (NSSSS) as the primary market and without base price. NSSSS is a market that all Non-usury securities can be transacted in, (Bidabad and Allahyarifard, 2010). NSSSS sub-systems are: Real Time Gross Settlement System (RTGS), Automatic Clearing House (ACH), International Bank Account Number (IBAN), digital certificate and signature (PKI) and electronic notary offices who will issue and confirm digital certificates and signatures.

The issuer will fix a deadline for the tender and receive competitive bids from the buyers. After the deadline, papers will be sold according to the highest bid to the buyer. Since the seller has not defined any price below the face value, and all principles of contract are fulfilled, the transaction will lawful as per Shariaa point of view and no skepticism of usury exists. The bonds can be re-transacted on the same internet platform of NSSSS as the secondary market. Transactions in both markets will be held according to purchase contract and through the tender procedure.

Interest-free bonds can be issued in domestic or foreign exchange on NSSSS as well. These bonds can also be sold 
by the issuer in primary market. Buyers should have an electronic account or ATM (Automatic Teller Machine) card accepted by the network or a creditable international exchange card for identification.

International Bank Account Number (IBAN) for transaction of interest-free bonds in NSSSS system can be used in electronic payments and settlements. When the bonds are bought in primary market, the secondary market is created in NSSSS system. Customers can enter into this market and may transact the bonds before maturity at competitive prices even for speculative purposes. Transaction records of people and entities will be traced in NSSSS system. The bonds will be sold in the first and second time periods at highest price offered in the secondary market. Automatic Clearing House (ACH), and Real Time Gross Settlement System (RTGS), for interbank settlement of small and large payments are inevitable in NSSSS.

\subsection{Collaterals}

For the first three types of interest-free bonds there is no need for extra collaterals due to the existing legal arrangements; but for the interest-free bonds to be issued by private entities certain collaterals are to be used.

In order to have information technology-based transaction efficiency in the secondary market, special mechanisms should be designed in the software so that the guarantees can also be bought and sold through confident banks when bonds will be issued, bought, sold or settled.

It may be possible to use other collaterals instead of bank guarantees, but may in turn reduce the efficiency of transaction of private interest-free bonds. To solve the problem, it is possible to establish an institution to have the authority to provide guarantees on the basis of collaterals. In this case, the issuer of papers may offer collaterals to these institutions and obtain guarantee certificate. In case, the issuer defaults to pay back the fund at maturity to the bond buyer, then the cited institution will transfer the ownership of the collateral to buyer. Furthermore, in the second time period of the bond, the same institution will obtain the same amount of collateral from the buyer for the interest of the seller and after the end of the second time period and paying back the fund - after the settlement - the guarantee will be canceled. These institutions can be affiliated, for instance, to Justice Department like notary public offices and may be supervised by that department.

\section{Conclusion}

Islamic financial instruments must have two main characteristics: (i) non-usury (interest-free) and (ii) efficiency in application for monetary policies, finance and liquidity management of monetary authorities, government and financial institutes (including banks and non-banks). Interest-free bonds are based on participatory structures with risk sharing by investors. Moreover, interest-free bonds under the central banking operation will be one of the best ways of showing investors how attractive the Islamic finance regime can be. The open market operation of these interest-free bonds can affect liquidity and other monetary variables such as general price level and interest and exchange rates and thereof, aggregate supply and demand in the economy and balance of payments through monetary expansion mechanism. Since conventional bonds include interest (riba) and hence they are not Shariaa compliant which are legally forbidden to be used by monetary authorities under the Islamic economy, interest-free bond offers a substitute for conventional bonds so that in addition to be interest-free, it can efficiently affect monetary expansion, and makes financing and liquidity management possible for monetary and banking sector of the economy. Interest-free bonds are simply applicable in both Islamic and conventional (interest-based) economies without any trouble.

In order to apply efficient policies through monetary expansion mechanism, central bank can issue interest-free bonds in NSSSS system and sell the bonds with a face value and without any coupon and with zero interest rate. These securities can be bought by commercial, specialized and those monetary institutes who have prudential and legal reserves at central bank. The purchase of these bonds will decrease the monetary base and thereof, liquidity of the economy in the first time period and increase it with the same amount at the second time period. These bonds can be issued and bought back in the framework of interest-free treasury bonds by government to perform appropriate fiscal policy. Issuance of these bonds by banks and other corporate entities to use excess balances of others entities has no effect on liquidity of the economy and can be used as a solution for decreasing liquidity risk cost and debt leverage. These bonds can also be accomplished by bank guarantees for payback guarantee and establishing some collateral institutes for providing digital guarantee certificates.

The secondary market of these bonds on the web and in NSSSS system with tenders with base price equal to face value and competitive offer during tender time, will give suitable transaction capability to the interest-free bonds. The yield of the bonds will depend on the market price. No base price below its face value will be considered for the interest-free bonds and competitive prices are offered by buyers on the basis of expected interest, exchange and inflation rates. On other words, expected natural interest rate in the first and second time periods will play a 
dominant role in the market to perform interest-free bonds' prices. In addition, the transaction mechanism designed for the interest-free bonds will create market efficiency and bonds' yields rates converge to real sector rate of return.

\section{References}

Ben Khediri K., Ben Ali M. S., and Ben-Khedhiri H. (2010). Bank-specific, Industry-specific and Macroeconomic Determinants of African Islamic Banks' Profitability, International Journal of Business and Management Science. Vol. $3, \mathrm{n}^{\circ} 1$.

Bidabad, B. (2004). Economic-juristic analysis of usury in consumption and investment loans and contemporary jurisprudence shortages in exploring legislator commandments. Proceeding of the 2nd International Islamic Banking Conference. Monash University of Malaysia. 9-10 September.

Bidabad, B. and Allahyarifard, M. (2010). IT-based usury-free financial innovations. Proceeding of ECDC 2010, 5th International Conference on e-Commerce in Developing Countries: with focus on e-Banking \& e-Insurance. ECDC 2010, 15-16 September.

Chapra, M. U. (1985). Toward Just a Monetary System. Journal of King Abdul Aziz University: Islamic Economics, Vol. 2, 109-115.

Fadzlan, S. (2007). Efficiency of Islamic Banking Industry: Non-Parametric Analysis with Non-Discretionary Input Variable. Islamic Economic Studies, Vol. 14 (1-2), 53-87.

Iqbal, $\mathrm{Z}$ and Mirakhor, A. (2006). An Introduction to Islamic Finance: Theory and Practice. John Wiley \& Sons (eds), Hoboken, NJ.

Jobst, A.A.(2007). The Economics of Islamic Finance and Securitization. Journal of Structured Finance, Vol. 13 (1), 1-12.

Mansoori, M. T. (2010). Fiqh Regulations on Finance and Business Transaction, Ulil Alba Institute, Pasca Sarjana Universitas Ibn Khaldun, Bogor, Indonesia.

Mills, P. S and Presley, J. R. (1999). Islamic Finance: Theory and Practices. Palgrave McMillan, USA.

Moody's (2007). Focus on the Middle East. Inside Moody's, Winter, p. 4.

Moody's (2008). Focus on the Middle East. Inside Moody's, Winter, p. 4.

Rabin, A. A. (2004). Monetary Theory, Edward Elgar Publishing, Massachusetts, USA.

Sole, J. (2007). Introducing Islamic banks into conventional banking system. Working Paper No. 07/175, IMF, Washington, DC.

Sundarajan, V., Marston, D. and Gaiath, S.(1998).Monetary Operations and Government Debt Management Under Islamic Banking. IMF Working Paper No. 98/144, IMF, Washington, DC.

Wilson, R. (2008). Innovative in the Structuring of Islamic sukuk securities. Humanomics, Vol. 24 (3), 170-181.

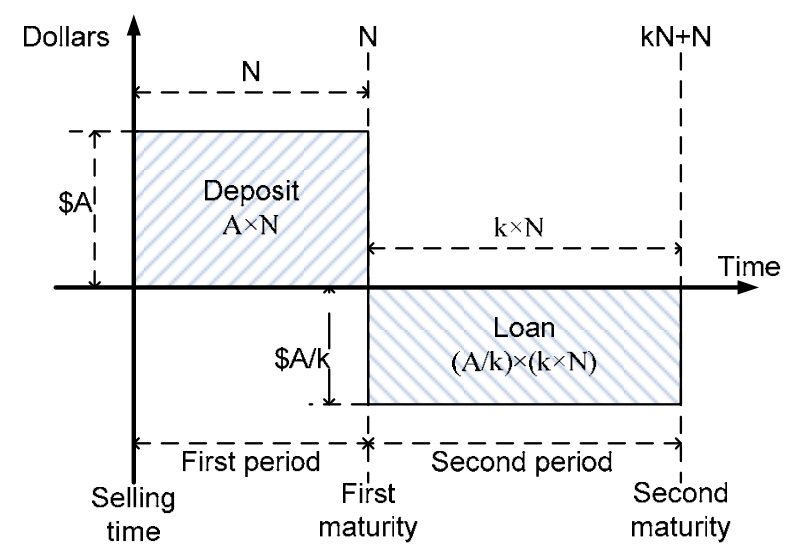

Figure 1. Two- Phases Maturity of Interest-free Bonds 